\title{
DAYA HIDUP SPERMATOZOA KAMBING PERANAKAN ETAWA YANG DIPRESERVASI DENGAN BERBAGAI JENIS PENGENCER
}

\author{
Muhammad Rizal ${ }^{1}$, Muhammad Thahir ${ }^{2}$ \\ ${ }^{1}$ Jurusan Peternakan, Fakultas Pertanian, Universitas Lambung Mangkurat, Jl. Jenderal Ahmad \\ Yani Km, 36 Banjarbaru 70714. Telp. 0511-4781551.*Email: mrizal@unlam.ac.id \\ ${ }^{2}$ Dinas Pertanian Kabupaten Enrekang, Jl. Poros Pinang - Rappang Km. 3 Enrekang 91712
}

\begin{abstract}
Abstrak
Tujuan penelitian ini adalah menguji efektivitas pengencer Tris, natrium sitrat, dan laktosa dalam mempertahankan daya hidup spermatozoa kambing peranakan etawa (PE) yang dipreservasi pada suhu $3-5^{\circ} \mathrm{C}$. Semen ditampung dengan vagina buatan satu kali dalam satu minggu sebanyak enam kali sebagai ulangan. Semen segar dibagi ke dalam tiga buah tabung reaksi, masingmasing diencerkan dengan pengencer Tris, natrium sitrat, dan laktosa sebagai perlakuan. Kemudian disimpan di dalam lemari es pada suhu $3-5^{\circ} \mathrm{C}$. Data dianalisis dengan rancangan acak lengkap dengan tiga perlakuan dan enam kali ulangan. Hasil penelitian menunjukkan bahwa volume semen segar kambing PE rata-rata 1,05 ml, warna krem, konsistensi kental, pH 6,9, gerakan massa ++ - +++, konsentrasi spermatozoa 3.756,67 juta sel/ml, spermatozoa motil $76,67 \%$, spermatozoa hidup $85,83 \%$, dan spermatozoa abnormal 4,5\%. Ketiga jenis pengencer memiliki kemampuan yang sama dalam mempertahankan daya hidup spermatozoa kambing PE selama preservasi. Pada hari keempat preservasi, persentase SM dan SH perlakuan Tris $(44,17$ dan $57,83 \%)$ tidak berbeda nyata dengan natrium sitrat (43,33 dan 56,67\%), dan laktosa $(43,33$ dan 54,17\%). Di simpulkan bahwa pengencer Tris, natrium sitrat, dan laktosa memiliki kemampuan yang sama dalam mempertahankan kualitas spermatozoa kambing PE selama preservasi pada suhu $3-5^{\circ} \mathrm{C}$. Pengencer Tris, natrium sitrat, dan laktosa mampu mempertahankan persentase spermatozoa motil sebesar $40 \%$ selama tiga hari preservasi pada suhu $3-5^{\circ} \mathrm{C}$, dan memenuhi syarat digunakan dalam program inseminasi buatan (IB).
\end{abstract}

Kata kunci: Tris, natrium sitrat, laktosa, daya hidup spermatozoa, kambing PE.

\begin{abstract}
The purpose of this research was to examine the effectivity of Tris, sodium citrate, and lactose extenders in maintaining viability of etawa crossbreed (EC) goat spermatozoa preserved at 3$5^{\circ} \mathrm{C}$. Semen was collected using artificial vagina once a week for six times as replicate. Fresh semen was divided into three tubes then diluted with Tris, sodium citrate, and lactose extenders, respectively. Diluted-semen were stored in refrigerator at $3-5^{\circ} \mathrm{C}$. Quality of diluted-semen including percentages of motile spermatozoa (MS) and live spermatozoa (LS) were evaluated every day during storage at $3-5^{\circ} \mathrm{C}$ for four days. Data were analyzed using completely randomized design with three treatments and six replicates. Results of this study showed that mean volume, colour, consistency, $\mathrm{pH}$, mass activity, spermatozoa concentration, MS, LS, and spermatozoa abnormal of PE goat fresh semen were $1.05 \mathrm{ml}$, cream, thick, $6.9,++-+++$, $3,756.67$ million cell $/ \mathrm{ml}, 76.67 \%, 85.83 \%$, and $4.5 \%$, respectively. Tris, sodium citrate, and lactose extenders have same ability in maintaining viability of EC goat spermatozoa during preserved at $3-5^{\circ} \mathrm{C}$. At day-4 storage, percentages of MS and LS for Tris (44.17 and 57.83\%) was no difference significant with sodium citrate (43.33 and 56.67\%), and lactose (43.33 and $54.17 \%$ ). In conclusion, Tris, sodium citrate, and lactose extenders have same ability in maintaining viability of EC goat spermatozoa during preserved at $3-5^{\circ} \mathrm{C}$. Tris, sodium citrate, and lactose extenders could be maintaining $40 \%$ in percentage of motile spermatozoa for three days after preserved at $3-5^{\circ} \mathrm{C}$, and suitable for use in artificial insemination (AI) program.
\end{abstract}

Keywords: Tris, sodium citrate, lactose, spermatozoa viability, PE goat. 


\section{PENDAHULUAN}

Kambing peranakan etawa (PE) merupakan hasil persilangan antara kambing etawa dan kambing lokal Indonesia yang memiliki kemampuan memproduksi susu cukup tinggi untuk daerah tropik. Kambing PE tersebut memiliki potensi yang besar untuk dikembangkan sebagai salah satu ternak penghasil susu di Indonesia, karena telah mampu beradaptasi secara baik dengan iklim di daerah tropik. Kambing tersebut juga dapat dimanfaatkan untuk meningkatkan potensi kambing-kambing lokal lainnya melalui persilangan dengan teknologi reproduksi, seperti inseminasi buatan (IB) (Souhoka et al., 2009).

Penerapan teknologi IB harus didahului dengan upaya pengolahan semen, yang terdiri atas: penampungan, pengenceran, dan penyimpanan semen. Unsur-unsur yang digunakan dalam menyusun pengencer semen terdiri atas beberapa bahan kimiawi yang berfungsi sebagai sumber energi, penyangga, pelindung spermatozoa, dan antibiotik sebagai unsur pengendali perkembangan mikroorganisme. Campbell et al. (2003) menyatakan bahwa bahan pengencer semen harus memiliki nutrisi yang cukup, $\mathrm{pH}$ sekitar 6,5-6,7, mengandung penyangga (buffer), serta mampu memberikan proteksi terhadap kontaminasi bakteri dan kejutan dingin (cold shock).

Sumber energi utama bagi spermatozoa adalah fruktosa, yang dimetabolisir sehingga dihasilkan adenosin trifosfat (ATP) sehingga spermatozoa tetap dapat gergerak (motil) (Paulenz et al., 2002). Hal ini karena fruktosa lebih mudah dimetabolisme oleh spermatozoa, sehingga umum diberikan pada pengencer semen cair dan semen beku pada berbagai jenis ternak (Vishwanath dan Shannon, 2000; Eiman et al., 2004). Kuning telur ayam juga merupakan salah satu bahan yang lazim digunakan dalam membuat suatu pengencer semen. Lesitin yang terkandung di dalam kuning telur ayam adalah alasan utama pemanfaatannya sebagai bahan penyusun pengencer semen. Lesitin dibutuhkan sebagai pelindung membran plasma sel spermatozoa untuk mencegah terjadinya kejutan dingin (cold shock) saat semen disimpan pada suhu dingin (Quinn et al., 1980; Watson, 1981).

Beberapa jenis pengencer telah diteliti dan diterapkan dalam proses pengolahan semen, seperti: susu segar, susu skim, tris kuning telur, sitrat kuning telur, dan laktosa kuning telur (Vishwanath dan Shannon, 2000) pada berbagai jenis ternak. Menurut Paulenz et al. (2002) masing-masing pengencer memiliki keistimewaan dan mampu memberikan pengaruh yang berbeda terhadap kualitas spermatozoa selama proses preservasi. Penelitian ini bertujuan untuk menguji kemampuan pengencer Tris, natrium sitrat, dan laktosa dalam mempertahankan daya hidup spermatozoa kambing PE selama preservasi pada suhu $3-5^{\circ} \mathrm{C}$.

MATERI DAN METODE

Penampungan dan Pengolahan Semen

Semen ditampung menggunakan vagina buatan satu kali dalam satu minggu dari satu ekor kambing PE dewasa yang berumur sekitar empat tahun. Penampungan semen dilakukan sebanyak enam kali sebagai jumlah ulangan.

Semen segar kambing PE yang telah ditampung segera dievaluasi untuk mengetahui kualitasnya. Semen yang memenuhi syarat kualitas (spermatozoa motil $\geq 70 \%$, gerakan massa ++ atau +++ , dan spermatozoa abnormal $<10 \%$ ) dibagi ke dalam tiga buah tabung reaksi yang berisi tiga jenis pengencer semen, yaitu: Tris, natrium sitrat, dan laktosa. Semen diencerkan hingga mencapai konsentrasi 100 juta spermatozoa motil 
setiap mililiter. Komposisi pengencer dasar Tris terdiri atas: 3,32 $\mathrm{g}$ Tris(hidroksimetil)aminometan, 1,86 $\mathrm{g}$ asam sitrat, dan $1,37 \mathrm{~g}$ fruktosa yang dilarutkan dengan akuabidestilata hingga mencapai volume $100 \mathrm{ml}$. Komposisi pengencer dasar natrium sitrat terdiri atas: 2,9 g natrium sitrat, 1,37 $\mathrm{g}$ fruktosa yang dilarutkan dengan akuabidestilata hingga mencapai volume $100 \mathrm{ml}$. Komposisi pengencer dasar laktosa terdiri atas: $9 \mathrm{~g}$ laktosa, 1,37 $\mathrm{g}$ fruktosa yang dilarutkan dengan akuabidestilata hingga mencapai volume $100 \mathrm{ml}$. Masing-masing pengencer mengandung $20 \%$ kuning telur ayam ras dan ditambahkan antibiotik berupa $1.000 \mathrm{IU}$ penisilin dan $1.000 \mu \mathrm{g}$ streptomisin setiap mililiter pengencer.

Ketiga tabung reaksi yang berisi semen masing-masing perlakuan ditutup rapat kemudian dimasukkan ke gelas piala yang telah diisi air bersih dan disimpan di dalam refrigerator lemari es pada suhu $3-5^{\circ} \mathrm{C}$. Semen masingmasing perlakuan dievauasi kualitasnya setiap hari selama empat hari hingga persentase spermatozoa motil mencapai 40\% (SNI 4869.3-2014).

\section{Variabel Kualitas Semen yang Dievaluasi}

Kualitas semen dievaluasi pada tahap setelah penampungan (semen segar), pengenceran, dan selama penyimpanan. Kualitas semen yang dievaluasi pada tahap semen segar adalah: volume, warna, kekentalan (konsistensi), pH (derajat keasaman), konsentrasi spermatozoa, gerakan massa spermatozoa, persentase spermatozoa motil, persentase spermatozoa hidup, dan persentase spermatozoa abnormal. Kualitas spermatozoa yang dievaluasi setelah pengenceran dan penyimpanan meliputi: persentase spermatozoa motil dan persentase spermatozoa hidup.

Persentase spermatozoa motil: persentase spermatozoa yang bergerak progresif (bergerak ke depan). Dievaluasi secara subyektif pada delapan lapang pandang yang berbeda dengan mikroskop cahaya pembesaran 400x (Rasul et al., 2001). Angka yang diberikan berkisar antara 0 dan 100\% dengan skala $5 \%$.

Persentase spermatozoa hidup: persentase spermatozoa yang hidup. Dievaluasi dengan pewarnaan eosinnigrosin (Felipe-Perez et al., 2008). Spermatozoa yang hidup ditandai oleh kepala berwarna putih atau transparan, sedangkan yang mati ditandai oleh kepala berwarna merah. Sebanyak minimum 200 spermatozoa dievaluasi dengan mikroskop cahaya pembesaran 400x.

\section{Analisis Data}

Data dianalisis dengan analisis ragam dalam bentuk rancangan acak lengkap dengan tiga perlakuan dan enam kali ulangan. Perbedaan antarperlakuan diuji dengan uji beda nyata terkecil (Steel dan Torrie, 1993).

\section{HASIL DAN PEMBAHASAN}

\section{Karakteristik Semen Segar Kambing PE}

Hasil penelitian diperoleh volume semen segar rata-rata 1,05 $\mathrm{ml}$ (Tabel 1). Peneliti sebelumnya melaporkan volume semen kambing PE yang bervariasi, yakni: rata-rata 1,52 $\mathrm{ml}$ (Hastono et al., 1998), 0,95 ml (Tambing et al., 2001), $1,42 \mathrm{ml}$ (Yusuf et al., 2005), 0,68 ml (Souhoka et al., 2009), 0,9 ml (Winarto dan Isnaini, 2008), 1,9 ml (Heriyanta et al., 2013), 0,87 ml (Kaka et al., 2014), dan 1,5 ml (Rizal et al., 2014). 
Tabel 1. Karakteristik Semen Segar kambing PE

\begin{tabular}{lc}
\hline Variabel & Rata-rata \pm SD \\
\hline Volume (ml) & $1,05 \pm 0,17$ \\
Warna & Krem \\
Konsistensi (kekentalan) & Kental \\
Derajat keasaman (pH) & $6,90 \pm 0,10$ \\
Gerakan massa spermatozoa & ++-+++ \\
Konsentrasi spermatozoa (juta sel/ml) & $3.756,67 \pm 295,01$ \\
Persentase spermatozoa motil $(\%)$ & $76,67 \pm 2,58$ \\
Persentase spermatozoa hidup $(\%)$ & $85,83 \pm 2,48$ \\
Persentase spermatozoa abnormal $(\%)$ & $4,50 \pm 1,05$ \\
\hline
\end{tabular}

Warna semen segar yang diperoleh adalah krem dan konsistensi kental (Tabel 1). Warna semen segar kambing PE adalah putih hingga krem dengan konsistensi agak kental hingga kental (Tambing et al., 2001; Yusuf et al., 2005; Winarto dan Isnaini, 2008; Souhoka et al., 2009). Menurut Evans dan Maxwell (1987) warna semen segar kambing yang normal adalah putih hingga krem. Selanjutnya dinyatakan bahwa semen segar yang memiliki jumlah spermatozoa banyak akan mengakibatkan semen lebih kental dan berwarna lebih pekat.

Gerakan massa spermatozoa yang diperoleh adalah ++ hingga +++ dengan $\mathrm{pH}$ rata-rata 6,9 (Tabel 1). Gerakan massa spermatozoa kambing PE adalah ++ hingga +++ (Tambing et al., 2001; Yusuf et al., 2005; Winarto dan Isnaini, 2008; Souhoka et al., 2009; Kaka et al., 2014; Rizal et al., 2014). Derajat keasman $(\mathrm{pH})$ semen segar kambing PE berkisar antara 6,6 dan 7,13 (Suwarso, 1999; Yusuf et al., 2005; Souhoka et al., 2009; Kaka et al., 2014).

Hasil penelitian diperoleh konsentrasi spermatozoa rata-rata 3.756,67 juta sel/ml (Tabel 1). Peneliti sebelumnya melaporkan konsentrasi spermatozoa kambing PE yang bervariasi, yaitu: rata-rata 2.070 juta $\mathrm{sel} / \mathrm{ml}$ (Hastono et al., 1998), 2.940 juta $\mathrm{sel} / \mathrm{ml}$ Tambing et al. (2001), 2.806,3 juta sel/ml (Yusuf et al., 2005), 3.344 juta sel/ml (Winarto dan Isnaini, 2008), 4.148,57 juta sel/ml (Souhoka et al., 2009), 2.434,75 juta sel/ml (Heriyanta et al., 2013), 3.756 juta $\mathrm{sel} / \mathrm{ml}$ (Rachmawati et al., 2013), 1.741,17 juta sel/ml (Kaka et al., 2014), dan 2.140 juta $\mathrm{sel} / \mathrm{ml}$ (Rizal et al., 2014). Menurut Evans dan Maxwell (1987) konsentrasi spermatozoa kambing yang normal berkisar antara 2.500 juta dan 5.000 juta $\mathrm{sel} / \mathrm{ml}$.

Persentase spermatozoa motil yang diperoleh pada penelitian ini adalah ratarata $76,67 \%$ dan persentase spermatozoa hidup rata-rata $85,83 \%$ (Tabel 1). Persentase spermatozoa motil dan spermatozoa hidup semen segar kambing PE masing-masing rata-rata 50 dan 64,75\% (Hastono et al., 1998), 78,13 dan 94,08\% (Suwarso, 1999), 72,79 dan $82,54 \%$ (Tambing et al., 2001), 77,5 dan 83,95\% (Yusuf et al., 2005), 79 dan 90,75\% (Winarto dan Isnaini, 2008), 70 dan 83,895 (Souhoka et al., 2009), 63,13\% (Rachmawati et al., 2013), 75 dan 85\% (Akmal et al., 2014), serta 76,67 dan 81,45\% (Kaka et al., 2014).

Persentase spermatozoa abnormal yang diperoleh adalah rata-rata $4,5 \%$ (Tabel 1). Persentase spermatozoa abnormal kambing PE rata-rata $17 \%$ (Hastono et al., 1998), 10,17\% (Tambing et al., 2001), 4,59\% (Yusuf et 
al., 2005), 15,78\% (Winarto dan Isnaini, 2008), 7,12\% (Souhoka et al., 2009), dan 10,35\% (Kaka et al., 2014). Menurut Delgadillo (1992) persentase spermatozoa abnormal kambing yang normal adalah sekitar 6-10\%.

Berdasarkan pada data karakteristik semen segar tersebut di atas diperoleh hasil yang bervariasi antarindividu kambing PE. Hal ini disebabkan oleh perbedaan potensi genetik masingmasing individu, manajemen, frekuensi penampungan, dan lain-lain (Toelihere, 1981). Semen segar kambing PE yang digunakan dalam penelitian ini memiliki semen dengan kualitas yang baik dan memenuhi syarat untuk diproses lebih lanjut, baik dalam bentuk semen cairdingin maupun semen beku. Hal ini karena semen segar tersebut memiliki konsistensi agak kental hingga kental, gerakan massa spermatozoa ++ dan +++ , persentase spermatozoa motil $76,67 \%$, dan persentase spermatozoa abnormal $4,5 \%$. Semen segar yang baik harus memiliki konsistensi agak kental atau kental dan gerakan massa ++ atau +++
(Toelihere, 1981), persentase spermatozoa motil $\geq 70 \%$ (Evans dan Maxwell, 1987), dan persentase spermatozoa abnormal kurang dari $10 \%$ (Delgadillo, 1992).

\section{Kualitas Spermatozoa setelah Preservasi pada Suhu $3-5^{\circ} \mathrm{C}$}

Hasil penelitian menunjukkan bahwa secara statistik tidak ada perbedaan yang nyata antarperlakuan terhadap kualitas spermatozoa kambing PE selama preservasi pada suhu $3-5^{\circ} \mathrm{C}$. Nilai persentase spermatozoa motil (Tabel 2) dan spermatozoa hidup (Tabel 3) yang diencerkan dengan pengencer Tris, natrium sitrat, dan laktosa relatif sama mulai dari hari pertama hingga hari kelima preservasi. Hal ini menunjukkan bahwa senyawa kimia yang terkandung di dalam ketiga jenis pengencer tersebut memiliki kemampuan yang sama dalam melindungi spermatozoa dari proses kerusakan selama preservasi pada suhu rendah $\left(3-5^{\circ} \mathrm{C}\right)$.

Tabel 2. Rata-rata persentase spermatozoa motil selama preservasi pada suhu $3-5^{\circ} \mathrm{C}$

\begin{tabular}{lccccc}
\hline Perlakuan & \multicolumn{5}{c}{ Penyimpanan hari ke- } \\
\cline { 2 - 6 } & 1 & 2 & 3 & 4 & 5 \\
\hline Tris & $76,67 \pm 2,58$ & $70,00 \pm 0,00$ & $53,44 \pm 4,08$ & $44,17 \pm 3,76$ & $25,00 \pm 4,47$ \\
Na sitrat & $76,67 \pm 2,58$ & $69,17 \pm 2,04$ & $52,50 \pm 2,74$ & $43,33 \pm 2,58$ & $22,50 \pm 2,74$ \\
Laktosa & $76,67 \pm 2,58$ & $69,17 \pm 2,04$ & $56,67 \pm 2,58$ & $43,33 \pm 2,58$ & $25,73 \pm 3,76$ \\
\hline
\end{tabular}

Preservasi semen pada suhu rendah akan menyebabkan terjadi kerusakan membran plasma sel spermatozoa akibat pengaruh kejutan dingin yang dapat berakibat terhadap kematian sel. Menurut White (1993) pengaruh kejutan dingin berkaitan dengan perubahan fosfolipid yang menyusun membran plasma sel, yakni perubahan bentuk dari cair ke gel yang terjadi pada suhu di bawah $20^{\circ} \mathrm{C}$. Perubahan tatanan rantai asam lemak dan protein pada membran plasma menyebabkan kebocoran atau selektivitas membran plasma rusak, yang menyebabkan ion-ion seperti ion kalsium bebas masuk ke sel. Dampak negatif utama yang timbul akibat kejutan dingin adalah menurunnya motilitas spermatozoa karena terjadinya kontraksi selubung lipoprotein membran plasma sel, sehingga memecah selubung lipoprotein membran plasma sel dan menyebabkan keluarnya substansi intraseluler yang vital. Oleh karena itu, menurut Kayser et al. (1992) dalam preservasi spermatozoa pada suhu yang mendekati $0^{\circ} \mathrm{C}$ diperlukan zat pelindung di dalam pengencer, seperti fosfolipid 
kuning telur dan krioprotektan, serta proses pendinginan harus dilakukan secara bertahap. Untuk mengurangi pengaruh kejutan dingin selama preservasi semen pada suhu rendah, para peneliti di bidang preservasi semen umumnya menambahkan susu atau kuning telur ayam di dalam pengencer (Aku et al., 2007; Andrabi et al., 2008; Akhter et al., 2010). Di dalam ketiga jenis pengencer yang digunakan dalam penelitian ini terdapat kuning telur ayam yang mengandung fosfolipid berupa fosfatidil kolin (lesitin). Briand-Amirat et al. (2007) menyatakan bahwa lesitin yang ada di dalam kuning telur mengandung gliserol, asam lemak sederhana, fosfat, dan kolin. Lipoprotein kuning telur berinteraksi dengan lipoprotein membran plasma sel spermatozoa dan melindungi spermatozoa dari pengaruh kejutan dingin yang pada akhirnya dapat mempertahankan motilitas dan viabilitas spermatozoa (Morton et al., 2010).

Tabel 3. Rata-rata Persentase Spermatozoa Hidup selama Preservasi pada Suhu $3-5^{\circ} \mathrm{C}$

\begin{tabular}{lccccc}
\hline Perlakuan & \multicolumn{5}{c}{ Penyimpanan hari ke- } \\
\cline { 2 - 6 } & 1 & 2 & 3 & 4 & 5 \\
\hline Tris & $85,50 \pm 1,52$ & $80,33 \pm 1,63$ & $65,50 \pm 3,62$ & $57,83 \pm 3,87$ & $38,50 \pm 2,59$ \\
Na sitrat & $84,33 \pm 1,97$ & $79,17 \pm 1,47$ & $67,17 \pm 1,83$ & $56,67 \pm 1,86$ & $36,67 \pm 1,63$ \\
Laktosa & $85,00 \pm 2,10$ & $80,17 \pm 1,60$ & $65,50 \pm 1,05$ & $54,17 \pm 1,17$ & $36,50 \pm 0,55$ \\
\hline
\end{tabular}

Karbohidrat yang terkandung di dalam pengencer Tris, natrium sitrat, dan laktosa berperan sebagai senyawa krioprotektan ekstraseluler, yang berfungsi melindungi membran plasma sel spermatozoa dari proses perusakan akibat pengaruh kejutan dingin selama penyimpanan pada suhu rendah $\left(3-5^{\circ} \mathrm{C}\right)$. Karbohidrat merupakan senyawa yang dapat berperan sebagai krioprotektan ekstraseluler, dan berfungsi melindungi membran plasma sel dari kerusakan (Supriatna dan Pasaribu, 1992). Menurut Viswanath dan Shannon (2000) senyawa krioprotektan golongan karbohidrat memiliki kemampuan menggantikan molekul air secara normal dalam kelompok polar hydrated. Sifatsifat karbohidrat ini akan membantu menstabilkan membran plasma sel spermatozoa selama masa transisi melewati zona suhu yang kritis, serta mengubah sifat mekanik pengencer melalui peningkatan viskositas. Di samping itu, karbohidrat juga berfungsi sebagai substrat yang akan dimetobilisir oleh spermatozoa untuk menghasilkan energi berupa adenosine trifosfat (ATP) sehingga spermatozoa dapat bergerak (motil) (Paulenz et al., 2002; Vishwanath dan Shannon, 2000; Eiman et al., 2004).

Hasil penelitian ini menunjukkan bahwa pengencer Tris, natrium sitrat, dan laktosa mampu mempreservasi spermatozoa kambing PE pada suhu 3$5^{\circ} \mathrm{C}$ selama tiga hari dan masih layak digunakan dalam program IB, karena memiliki persentase spermatozoa motil masing-masing sebesar 44, 43, dan $43 \%$. Semen kambing yang memenuhi syarat digunakan dalam program IB harus memiliki persentase spermatozoa motil minimum 40\% (SNI 4869.3-2014).

\section{KESIMPULAN}

Berdasarkan hasil penelitian ini dapat disimpulkan bahwa pengencer Tris, natrium sitrat, dan laktosa memiliki kemampuan yang sama dalam mempertahankan kualitas spermatozoa kambing PE selama preservasi pada suhu $3-5^{\circ} \mathrm{C}$. Pengencer Tris, natrium sitrat, dan laktosa mampu mempertahankan persentase spermatozoa motil sebesar $40 \%$ selama 
tiga hari preservasi pada suhu $3-5^{\circ} \mathrm{C}$, dan memenuhi syarat digunakan dalam program IB.

\section{DAFTAR PUSTAKA}

Akhter, S., M.S. Ansari, B.A. Rakha, S.M.H. Andrabi, M. Anwar, and N. Ullah. 2010. Effect of fructose addition in skim milk extender on the quality of liquid nili-ravi buffalo (Bubalus bubalis) semen. Pakistan J. Zool. 42:227231.

Akmal, M., T.R. Ferasyi, H. Budiman, Razali, Azhari, Anwar, F.A. Pamungkas, S. Nasution, T. Armansyah, M. Hambal, Syafruddin, dan A. Sayuti. 2014. Suplemen bungkil inti sawit tepung daun katuk berpotensi meningkatkan kualitas spermatozoa pada kambing peranakan ettawa. Jurnal Kedokteran Hewan 8:142-146.

Aku, A.S., N. Sandiah, P.D. Sadsoitoeban, M.R. Amin, dan Herdis. 2007. Manfaat lesitin nabati pada preservasi dan kriopreservasi semen: Suatu kajian pustaka. Anim. Prod. 9:49-52.

Andrabi, S.M.H., M.S. Ansari, N. Ullah, M. Anwar, A. Mehmood, and S. Akhter. 2008. Duck egg yolk in extender improves the freezability of buffalo bull spermatozoa. Anim. Reprod. Sci. 104:427-433

Briand-Amirat, L., D. Tainturier, and M. Anton. 2007. Use of Egg Compounds for Cryoprotection of Spermatozoa. In Bioactive Egg Compounds. Huopalahti, R., R. López-Fandin o, M. Anton, and R. Schade (Eds.). Springer, New York

Campbell, J.R., M.D. Kenealy, and K.L. Campbell. 2003. Animal Science. 4th Ed. New York: Mc Graw-Hill.
Delgadillo, J.J., B. Leboeuf, and P. Chemineau. 1992. Abolition of seasonal variations in semen quality and maintenance of sperm fertilizing ability by photoperiodic cycles in goat bucks. Small Rum. Res. 9:47-59.

Eiman, M., E. Aboagla, and T. Terada. 2004. Effects of egg yolk during the freezing step of cryopreservation on the viability of goat spermatozoa. Theriogenology 62:1160-1172.

Evans, G. and W.M.C. Maxwell. 1987. Salamon's Artificial Insemination of Sheep and Goats. Butterworths, London.

Felipe-Perez, Y.E., M.L. JuarezMosqueda, E.O. HernandezGonzalez, and J.J. Valencia. 2008. Viability of fresh and frozen bull sperm compared by two staining techniques. Acta Vet. Bras. 2:123130.

Hastono, I.M. Budiarsana, R.S.G. Sianturi, U. Adiati, dan D. Yulistiani. 1998. Kualitas semen kambing PE pada umur yang berbeda di Kecamatan Kaligesing. Di dalam: Prosiding Seminar Nasional Peternakan dan Veteriner. Bogor, 1-2 Desember 1998. Hlm. 324-327

Heriyanta, E., M.N. Ihsan, dan N. Isnaini. 2013. Pengaruh umur kambing peranakan etawah (PE) terhadap kualitas semen segar. Jurnal Ternak Tropika 14:1-5.

Kaka, A., Nalley, W.M.M., P. Kune, dan Burhanuddin. 2014. Persentase nira lontar (Borassus flabellifer $\mathrm{L}$ ) dalam pengencer Tris-kuning telur terhadap kualitas semen cair kambing peranakan etawah yang disimpan suhu $3-5{ }^{\circ} \mathrm{C}$. Jurnal Nukleus Peternakan 1:21-27. 
Kayser, J.P., R.P. Amann, R.K. Shidefer, E.L. Squires, D.J. Jasko, and B.W. Pickett. 1992. Effects of liniar cooling rate on motion characteristics of stallion spermatozoa. Theriogenology 30:601-614.

Morton, K.M., G. Evans, and W.M.C. Maxwell. 2010. Effect of glycerol concentration, Equex STM supplementation and liquid storage prior to freezing on the motility and acrosome integrity of frozen-thawed epididymal alpaca viguna pacos sperm. Theriogenology 74:311-316

Paulenz, H., L. Soderquist, R. Perez-Pe, and K.A. Berg. 2002. Effect of different extenders and storage temperatures on sperm viability of liquid ram semen. Theriogenology 57:823-836.

Quinn, P.J., P.Y.W. Chow, and I.G. White. 1980. Evidence that phospholipid protects ram spermatozoa from cold shock at plasma membrane site. J. Reprod. Fertil. 60:403-407.

Rachmawati, L., Ismaya, dan P. Astuti. 2013. Level of testosterone, libido, and sperm quality of bligon, kejobong, and etawah cross-bred bucks. Animal Production 15:76-82.

Rasul, Z., N. Ahmad, and M. Anzar. 2001. Changes in motion characteristics, plasma membrane integrity and acrosome morphology during cryopreservation of buffalo spermatozoa. J. Androl. 22:278283.

Rizal, M., B. Irawan, D. Biyatmoko, A. Wahdi, Habibah, dan M. Riyadhi. 2014. Keberhasilan kebuntingan kambing peranakan ettawa yang diinseminasi dengan semen cair. Agrinimal 4:1-4.
SNI (Standar Nasional Indonesia). 2014. Semen Beku Kambing dan Domba. Jakarta: Badan Standardisasi Nasional (BSN).

Souhoka, D.F., M.J. Matatula, M.M.M. Nalley, dan M. Rizal. 2009. Laktosa mempertahankan daya hidup spermatozoa kambing peranakan etawah yang dipreservasi dengan plasma semen domba priangan. Jurnal Veteriner 10:135-142.

Steel, R.G.D dan J.H. Torrie. 1993. Prinsip dan Prosedur Statistika, Suatu Pendekatan Biometrik. Alih bahasa: B. Sumantri. Gramedia Pustaka Utama, Jakarta.

Supriatna, I. dan F.H. Pasaribu. 1992. In Vitro Fertilisasi, Transfer Embrio, dan Pembekuan Embrio. Pusat Antar Universitas, Institut Pertanian Bogor, Bogor.

Suwarso. 1999. Peranan Rafinosa dalam Pengencer Tris-SitratKuning Telur terhadap Kualitas Semen Beku Kambing Peranakan Etawah. Tesis. Program Pascasarjana, Institut Pertanian Bogor, Bogor.

Tambing, S.N., M.R. Toelihere, T.L. Yusuf, dan I.K. Sutama. 2001. Kualitas semen beku kambing Peranakan Etawah setelah ekuilibrasi. Hayati 8:70-75.

Toelihere, M.R. 1981. Inseminasi Buatan pada Ternak. Angkasa, Bandung.

Viswanath, R. and P. Shannon. 2000. Storage of bovine semen in liquid frozen state. Anim. Reprod. Sci. 62:23-53.

Watson, P.F. 1981. The roles of lipid and protein in the protection of ram spermatozoa at $5^{\circ} \mathrm{C}$ by egg yolk lipoprotein. J. Reprod. Fertil. 62:483-492. 
White, I.G. 1993. Lipid and Ca uptake of sperm in relation to cold shock and preservation: A review. Reprod. Fertil. Dev. 5:639-658.

Winarto, A. dan N. Isnaini. 2008. Pengaruh tingkat pengenceran terhadapkualitas spermatozoa kambing PE setelah penyimpanan pada suhu kamar. Jurnal Ternak Tropika 9:72-80.

Yusuf, T.L., R.I. Arifiantini, dan N. Rahmiwati. 2005. Daya tahan semen cair kambing peranakan etawah dalam pengencer kuning telur dengan kemasan dan konsentrasi spermatozoa yang berbeda. Jurnal Pengembangan Peternakan Tropis 30:217-223. 